Dhaka Univ. J. Biol. Sci. 23(2): 179-185, 2014 (July)

\title{
GROWTH AND YIELD OF BARI MUNG-5 (VIGNA RADIATA L. WILCZEK) FOLLOWING TIBA APPLICATION
}

\author{
A. M. M. Golam AdAM ${ }^{1}$ AND NARgis JAHAN* \\ Plant Physiology Laboratory, Department of Botany, University of Dhaka, \\ Dhaka-1000. Bangladesh
}

Key words: BARI Mung-5, TIBA, Growth, Yield

\begin{abstract}
An experiment was conducted to evaluate the effect of TIBA $(0,20,50,100$, $150 \mathrm{mg} / \mathrm{l}$ ) on the growth and yield attributes of BARI Mung-5 laid out in RBD. Plant height decreased due to TIBA treatments. Number of branches and leaves per plant were found to increase in all the treatments at all the ages of growth except at 7 DAS and the maximum number of branches and leaves were recorded due to $20 \mathrm{mg} / \mathrm{l}$ TIBA treatment. Dry matter per plant increased due to $20 \mathrm{mg} / \mathrm{l} \mathrm{TIBA}$ in most cases and was significantly highest at harvest. All the yield contributing characters showed positive response to $20 \mathrm{mg} / \mathrm{l}$ TIBA treatment. Number of pods and seeds per plant and fresh and dry weights of pods significantly differed from all other treatments. Increase in yield per plant and yield per hectare following $20 \mathrm{mg} / \mathrm{l}$ TIBA was 22.60 and $22.80 \%$ over the control, respectively. The highest harvest index was also recorded from $20 \mathrm{mg} / \mathrm{l}$ TIBA followed by control.
\end{abstract}

\section{Introduction}

Pulses are important source of protein for the greater part of the people of Bangladesh. Mungbean (Vigna radiata L. Wilczek) occupies about $8.10 \%$ of the total land used for the cultivation of pulses(1). Currently mungbean is being grown mostly in rotation with cereal crops due to its short duration, minimal input, least care and drought tolerant nature. The special characteristic of this variety is its synchronized maturity which is 10 - 15 days earlier than local cultivars. It also supplies a substantial amount of nitrogen to the succeeding non-legume crops grown in rotation(2). About 6.01 million tons of pulse is required to meet the present per capita requirement for the burgeoning population of the country(3). But, the average yield is very low in comparison to some other countries of the world.

TIBA (2, 3, 5-triiodo benzoic acid), a synthetic growth regulator is used for checking the excessive vegetative growth and lodging tendency, reducing the abscission of flowers and immature pods and for modification of crop canopy to improve the productivity of crops. Application of TIBA induce greater growth, yield and yield attributes of various economically important crop plants viz. soybean ${ }^{(4-7)}$, okra ${ }^{(8)}$, bottlegourd ${ }^{(9)}$, groundnut ${ }^{(10)}$, tomato ${ }^{(11)}$, jatropha ${ }^{(12)}$, alfalfa ${ }^{(13)}$ and cotton ${ }^{(14)}$.

"Author for correspondence: <jahan.nargis@yahoo.com>. 1Department of Botany, Jagannath University, Dhaka-1100, Bangladesh.<adam_du04@yahoo.com>. 
But, the effect of TIBA on any variety of mungbean has not been studied in Bangladesh. Reports are also scanty regarding this aspect from elsewhere of the world (18). Therefore, the present work was undertaken to find out the effect of TIBA on growth, yield and yield attributes of BARI Mung- 5 .

\section{Materials and Methods}

A field experiment was conducted in the Botanical Garden of Dhaka University following a randomized block design with three replications. Fertilizers were applied at doses recommended by BARI $(45,100$ and $60 \mathrm{~kg} / \mathrm{ha}$ of urea, triple super phosphate and muriate of potash, respectively) at the time of final land preparation. Cow-dung was also mixed homogeneously at the rate of $7790 \mathrm{~kg} / \mathrm{ha}$. Seeds of BARI mung-5 were collected from BARI, Joydebpur, Gazipur. It is a bold-seeded, high yielding, photoinsensitive variety, tolerant to MYMV (Mungbean yellow mosaic virus) disease and widely adapted to mungbean growing areas in Bangladesh. Seeds were surface sterilized with $0.5 \%$ calcium hypochlorite and sown on $10^{\text {th }}$ March, 2011 in rows $30 \mathrm{~cm}$ apart. Size of the experimental plot was $51.30 \mathrm{~m}^{2}(9.5 \mathrm{~m} \times 4.5 \mathrm{~m})$. Weeding was done at 15 days after sowing followed by thinning to keep plant to plant distance of $10 \mathrm{~cm}$. Five treatments of TIBA $(0,20,50,100$ and $150 \mathrm{mg} / \mathrm{l})$ were applied as foliar spray at the age of 30 days after sowing.

Nine plants from each treatment were selected for data collection on plant height, number of branches and leaves per plant whereas nine other plants were harvested randomly for dry matter production. Data on plant height, number of branches, leaves and dry matter per plant were recorded at an interval of 7 days from the age of 30 days after sowing (date of foliar spray) up to harvest. Number of pods and seeds per plant, length of pod, fresh and dry weights of pods per plant, number of seeds per pod, 1000seed weight, yield per plant and harvest index were recorded after harvest. Data were analyzed statistically ${ }^{(16)}$.

\section{Results and Discussion}

Results presented in Table 1 indicated that plant height of BARI Mung- 5 reduced following TIBA application. Significantly tallest plant was obtained from the control treatment at all the ages followed by $20 \mathrm{mg}$ TIBA/l. The shortest plant was found from $100 \mathrm{mg}$ TIBA/l treatment at all the ages of growth with both significant and nonsignificant variations between the treatments. Similar results of decrease in plant height due to TIBA application have been reported by several workers on different plants viz. soybean $^{(6)}$ and cotton ${ }^{(14)}$.

Number of branches per plant was positively influenced by TIBA treatments at all ages of growth except at 7 DAS, where only increase in number of branches per plant was recorded due to $20 \mathrm{mg}$ TIBA/l treatment which was statistically at par with control 
(Table 1). After 7 DAS, number of branches per plant progressively increased following addition of different concentrations of TIBA and the maximum number (9 per plant) was recorded from $150 \mathrm{mg}$ TIBA/l followed by 100 and $20 \mathrm{mg}$ TIBA/l treatments, respectively (Table 1). Single foliar application of TIBA resulted significant increment in the number of branches in jatropha ${ }^{(12)}$. The present results are also consistent with the findings of other investigators $\left.{ }^{4}, 9\right)$. Application of TIBA did not affect number of branches per primary stem in alfalfa ${ }^{(13)}$. However, Jahan ${ }^{(7)}$ obtained increase in number of branches in one variety and decrease in the other variety of soybean.

Results showed positive response of TIBA on the number of leaves per plant at all the ages except at 7 DAS, where, leaf number was slightly decreased due to $150 \mathrm{mg}$ TIBA/l treatment (Table 2). However, after 7 DAS, number of leaves per plant showed similar trend of increase as in number of branches per plant and, thereafter, recovered to the maximum. The increases in number of leaves per plant due to highest concentration of TIBA i.e. $150 \mathrm{mg}$ TIBA/l were $41.69,45.47$ and $45.08 \%$ over the control at 14,21 and at harvest, respectively (Table 2). Number of leaves per plant increased with concentration of TIBA significantly over the control but variation between and among the treatments were not statistically significant at all. $\operatorname{Jahan}^{(7)}$ reported increase in leaf number of soybean var. Shohag due to $20 \mathrm{mg} / \mathrm{l}$ TIBA treatment. Significant increase in number of leaves per plants following 50, 100 and $150 \mathrm{mg} / \mathrm{l}$ TIBA application was also reported by Khan ${ }^{(17)}$ in soybean plant.

Data presented in Table 2 showed that dry matter (DM) per plant was affected significantly by different concentrations of TIBA at 14, 21 DAS and at harvest. Results also showed that dry matter per plant was found to increase only due to lowest concentration of TIBA at all the ages and the value was significantly higher from all other treatments at harvest only. This result is fully in agreement with the findings of Jahan (7) who observed that $20 \mathrm{mg} / \mathrm{l}$ TIBA increased the dry weight of soybean. By applying TIBA similar results of increase in dry matter was also reported by other investigators ${ }^{(5,17)}$.

Table 3 revealed that all the yield contributing characters were positively influenced by TIBA $(20 \mathrm{mg} / \mathrm{l})$. The maximum number of pods per plant were recorded from $20 \mathrm{mg}$ TIBA/l treatment which was significantly different from its other treatments except control. The increase in pods per plant was $9.65 \%$ higher over the control. However, the higher doses of TIBA reduced the number of pods per plant but not significantly. This result resembles to the findings of Jahan ${ }^{(7)}$ who observed that $20 \mathrm{mg} / \mathrm{l} \mathrm{TIBA}$ increased the number of fruits per plant in soybean varieties. Reports regarding increase in number of pod per plant are in conformity with the findings of several other investigators in different plants viz. soybean ${ }^{(4,5)}$, okra ${ }^{(8)}$, bottlegourd ${ }^{(9)}$, tomato ${ }^{(11)}$ and cotton ${ }^{(14)}$.

Length of pod was found to increase following the TIBA treatments but not significantly (Table 3$)$. The maximum pod length $(7.87 \mathrm{~cm})$ was obtained from both 20 and $150 \mathrm{mg}$ TIBA/l treatments. Fresh and dry weight of pods recorded were maximum due to $20 \mathrm{mg}$ TIBA/l treatment which was statistically identical with control but, significantly different from all other treatments. The increase in dry weight of pods due 


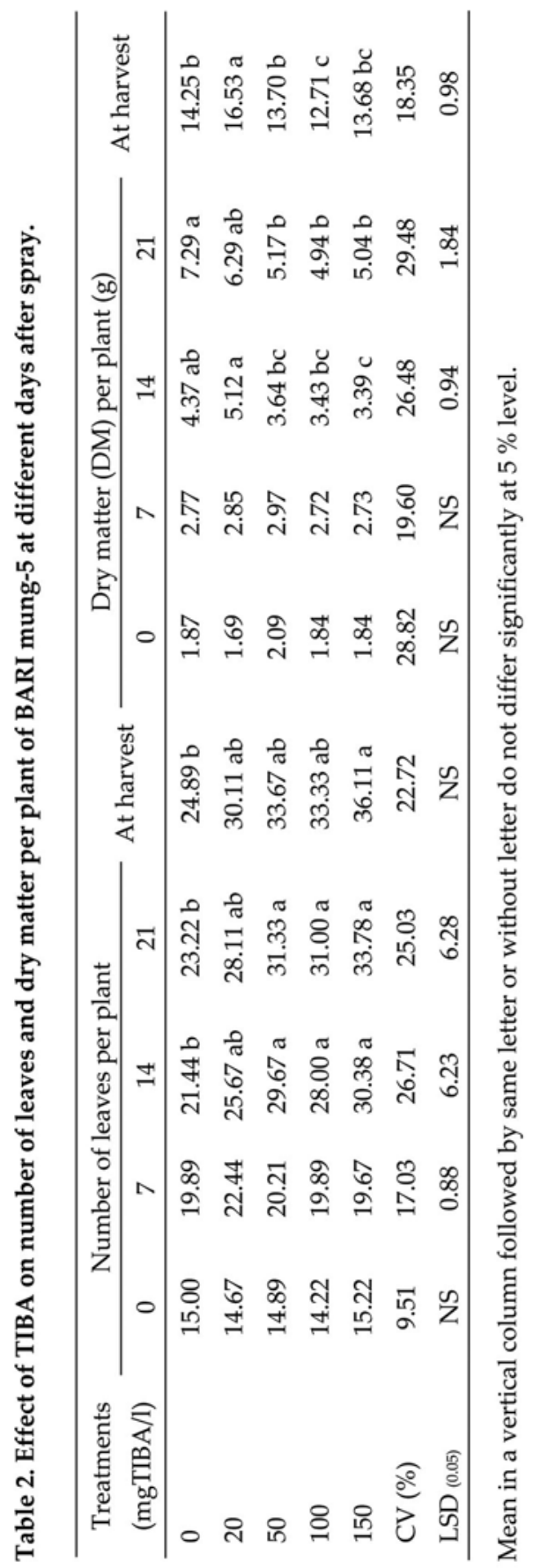




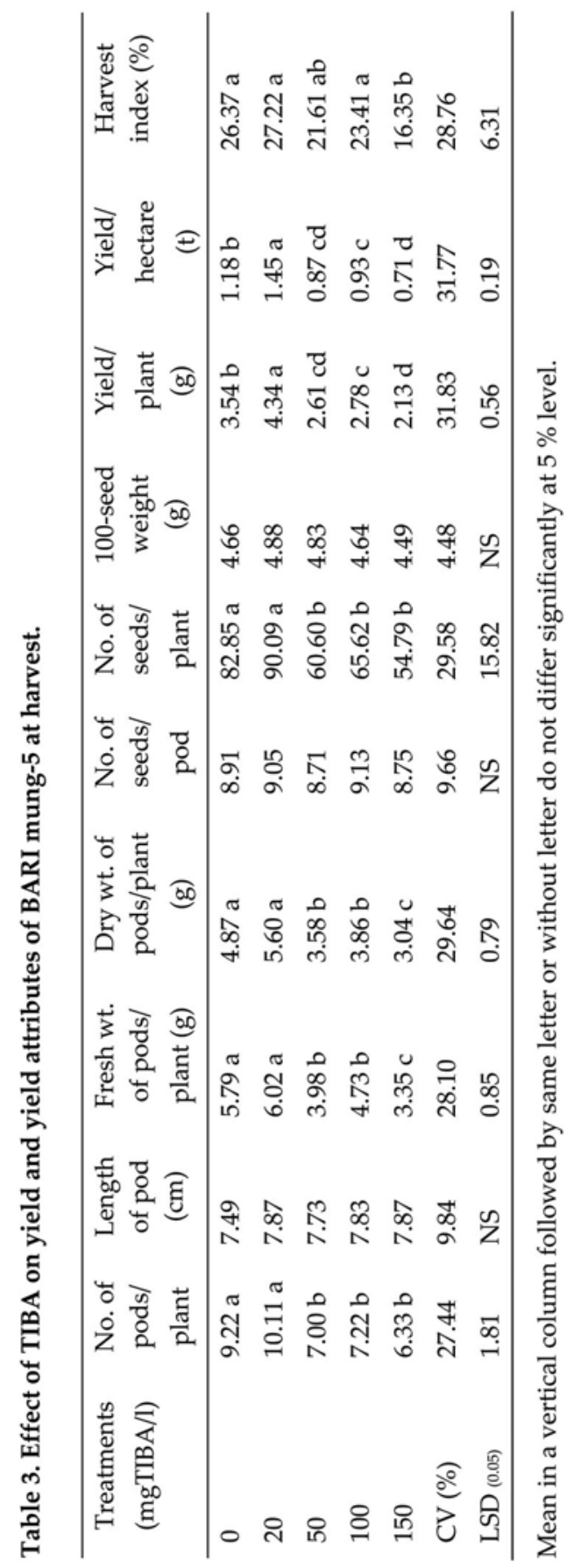


to TIBA treatment was $14.99 \%$ higher over the control. In contrast, higher concentration TIBA rendered a significantly depressing effect on both the fresh and dry weights of pods with concentration, in most of the cases, though the variation between the intermediate doses of TIBA was identical (Table 3). Results obtained in fresh and dry weights of pods is contradictory with the findings of Khan ${ }^{(17)}$ where pod weight of soybean decreased due to $20 \mathrm{mg} / \mathrm{l}$ TIBA treatments.

Different concentrations of TIBA showed both positive and negative responses in the number of seeds per pod but statistically not significant (Table 3). The highest number of seeds per pod (9.13) was obtained from plants treated with $100 \mathrm{mg}$ TIBA/l and it was $2.47 \%$ higher over the control followed by $20 \mathrm{mg}$ TIBA/l treatment. The maximum number of seed per plant (90.09) was counted from plants sprayed with $20 \mathrm{mg}$ TIBA/l which was significantly different from other plants treated with higher dose of TIBA but, statistically at par with control (Table 3). Jahan ${ }^{(7)}$ reported that $20 \mathrm{mg} / \mathrm{l} \mathrm{TIBA}$ increased the number of seeds per fruit in Shohag variety of soybean. Similar result of increase due to TIBA application was also reported by Ravichandran and Ramaswami(5). Results also showed that with the increasing concentration of TIBA over $50 \mathrm{mg} / \mathrm{l}$ caused a decrease in 100-seed weight (Table 3). Seed weight of mungbean increased up to $50 \mathrm{mg} / \mathrm{l}$ though the overall effect of the growth regulator was found to statistically insignificant. Due to $20 \mathrm{mg}$ TIBA/ 1 treatment seed weight increased by $4.72 \%$ as compared to control. Increases in seed weight following TIBA application were also reported by different investigators in okra $^{(11)}$ and soybean ${ }^{(5,7,17)}$. However, Chowdhury et al.(18) reported decreased seed weight in soybean var. EC-39752 due to $50 \mathrm{mg} / \mathrm{l}$ TIBA treatment.

Plants receiving $20 \mathrm{mg}$ TIBA/l resulted significantly maximum yield per plant (4.34 g) and yield per hectare (1.45 t) and the increases were 22.60 and $22.80 \%$ higher over the control, respectively (Table 3). Results revealed that higher concentrations of TIBA significantly decreased the yield of BARI Mung- 5 and the minimum reduction was recorded from $150 \mathrm{mg} / \mathrm{l}$ treated plant which was 39.83\% lower than the control. Increases in yield due to different concentrations of TIBA have already been noticed on other plants by many workers $(5-7,11,14)$. But, this result is not consistent with the findings of Khan (17) who obtained higher yield above the concentration of $20 \mathrm{mg} / \mathrm{l} \mathrm{TIBA}$ in soybean. The maximum harvest index (27.22\%) was obtained from plants sprayed with $20 \mathrm{mg}$ TIBA/1 which is significantly higher from that of the highest concentration $(16.35 \%)$ but at par with the intermediate doses of the growth regulator used together with the control (Table 3).

Findings from the present investigation indicated that the application of higher dose of TIBA $(150 \mathrm{mg} / \mathrm{l})$ although produced highest number of branches and leaves per plant, but, dry matter per plant decreased and yield per plant was the lowest. However, application of TIBA at $20 \mathrm{mg} / \mathrm{l}$ showed beneficial effects on all the yield contributing characters of BARI Mung-5 and thus leading to significant increase in grain yield. 


\section{References}

1. Kabir MH 2001. Krishitattik Gobeshona (in Bangla) (Agronomic Research). Text Book Division, Bangla Academy, Dhaka, Bangladesh. p. 400.

2. Sharma SN and R Prasad 1999. Effects of sesbania green manuring and mungbean residue incorporation of productivity and nitrogen uptake of a rice-wheat cropping system. Bioreso. Technol. 67(2): 171-175.

3. BARI (Bangladesh Agricultural Research Institute) 1998. Bangladesh-e Moog Daler Chash (in Bangla)-Mungbean Cultivation in Bangladesh. Pulse Research Station, Bangladesh Agril. Res. Inst. Joydebpur, Gazipur, Bangladesh. p. 45.

4. Chung IM and JK Kim 1989. Effect of plant growth regulator (TIBA, ABA, DGLP) treatment on growth and yield of soybean (Glycine max L.). Korean J. Crop Sci. 34(1): 1-6.

5. Ravichandran VK and C Ramaswami 1991. Effect of TIBA on yield and yield components of soybean in different seasons. Haryana J. Agron. 7(2): 120-122.

6. Deotale RD, DS Katekhaye, NV Store, JS Raut and VJ Golliwar 1995. Effect of TIBA and $\beta$ nine on morphological characters of soybean. J. Soils Crops 5: 172-176.

7. Jahan R 1998. Effect of TIBA, cycocel and mixtalol on two varieties of soybean grown in kharif and rabi season. M. Sc. Thesis, Dept. of Botany, University of Dhaka, Bangladesh.

8. Begum DA, QA Fattah and N Jahan 1992. Yield responses in Abelmoschus esculentus following KNap and TIBA application. Dhaka Univ. J. Biol. Sci. 1(1): 103-105.

9. Rahman MA and MM Rahman 1997. Effect of maleic hydrazide and triiodo benzoic acid on growth, sex expression and yield of Lagenaria siceraria (Mol.) Standl. J. Asiat. Soc. Bangladesh Sci. 23(2): 172-178.

10. Kler DS and GS Dhillon 1993. Effect of cycocel and TIBA spray on the pod yield of groundnut. Environ. Ecol. 11(2): 475.

11. Mondal MMA and RK Dutta 2002. Effect of TIBA (2,3,5-triiodobenzoic acid) on growth and yield of tomato. J. Agril. Res. 40(3-4): 273-279.

12. Abdelgadir HA, SD Johnson and J Van Staden 2009. Promoting branching of a potential biofuel crop Jatropha curcas L. by foliar application of plant growth regulators. Plant Growth Regulation 58(3): 287-295.

13. Phillips JC and DO Chilcote 1981. Growth and reproductive development of alfalfa as influenced by 2,3,5-triiodobenzoic acid. Can. J. Bot. 59: 373-376.

14. Djanaguiraman M, JA Sheeba, DD Devi and U Bangarusamy 2005. Response of cotton to atonilk and TIBA for growth, enzyme and yield. J. Biol. Sci. 5(32): 158-162.

15. Cagampang IC, OF Samson and JC Micosa 1978. Some studies on production management of mungbean at UPLB-CA (University of the Philippines at Los Banos, Coll. of Agriculture). Proc. of the 1st International Mungbean Symposium (Cowell R Eds.). pp. 89-92. Shanhua, Tainan, AVRDC.

16. Steel RGD and JH Torrie 1960. Principles and Procedures of Statistics. McGraw Hill, New York. pp. 480-482.

17. Khan S 2012. Physiological and biological responses of soybean (Glycine max L. Merrill var. BARI soybean-5) following triiodobenzoic acid (TIBA) application. MS Thesis. Department of Botany, University of Dhaka, Bangladesh.

18. Chowdhury JU, QA Fattah and Z Hussain 1978. Yield responses of three soybean varieties to TIBA application. Bangladesh J. Bot. 7(1): 93-96. 